\title{
International Arbitration Practices in Nigeria: A Construction Industry Appraisal
}

\author{
O. O. Ewa*, B. Haytham, E. E. Okon, O. P. Enang, D. A. Emiri
}

\begin{abstract}
This paper aims to investigate Corporate Alternative Conflict Management and Dispute Resolution compliance through an appraisal of International Arbitration practices in Project-based Organizations in the Nigerian Construction Industry. In this study, simple percentages and frequencies of occurrence were used to analyse data derived through subject matter interviews and a questionnaire survey. Using the Survey Monkey tool, 85 questionnaires were distributed to key players in the AEC (Architecture-Engineering-Construction) Industry including Engineers, Project Managers, Architects and Quantity Surveyors and 53 were returned complete. The survey indicated that $66 \%$ preferred a more private Construction Arbitration to a public Litigation as a preferred method of dispute resolution, with $65 \%$ agreeing that a lack of proper project funding hinders the arbitration process in the Nigerian Construction Industry. 66\% agree that Arbitration Time contributes more to project delays while $32 \%$ believe that Cost of the arbitration process is the greater source of project delays. We recommend that issues of confidentiality be carefully managed in dealing with outside counsels, while Project-based Organisations in Nigeria should ensure to develop master plans compatible with long-term strategies, including setting aside adequate funding for the timely resolution of project disputes through the implementation of only Arbitration-friendly contracts. This paper contributes to knowledge by bringing to bear the current compliance levels of project-based organisations in the practice of Arbitration in the Nigerian Construction Industry.
\end{abstract}

Index Terms - Alternative Dispute Resolution (ADR), Arbitration, Construction Industry, Project-based Organisations.

\section{INTRODUCTION}

The construction sector is regarded as one of the major sectors with regards to infrastructural development in any society. It is responsible for the execution of several projects. A project no matter how small involves the mobilization of different kinds of workforce. Before a project is executed the clients and contractors must go into an agreement which legally binds them to the obligations agreed upon.

\footnotetext{
O. O. Ewa, Civil Engineering Department, Cross River University of Technology, Calabar, Nigeria

B. Haytham, MACE School, The University of Manchester, Manchester, UK

E. E. Okon, Civil Engineering Department, Cross River University of Technology, Calabar, Nigeria

O. P. Enang, Civil Engineering Department, Cross River University of Technology, Calabar, Nigeria

D. A. Emiri, Civil Engineering Department, Cross River University of Technology, Calabar, Nigeria
}

The construction industry is regarded as one of the most conflict and dispute ridden industries which has resulted in it being one of the claims-orientated sectors.

Construction Arbitration is a prime factor to consider when preparing a contract, as no matter how little a project dispute is, could take a long period of time to resolve, and it is often too expensive and sophisticated.

Over the years, various methods of Alternative Dispute Resolution (ADR) have been introduced into construction industry as a means to avoid lengthy and expensive litigation, as conflict management is seen as the process of limiting the negative aspect of conflict while increasing the positive aspect of conflict [1], with the aim being to enhance learning and group outcomes, including effectiveness or performance in organisational setting.

Dispute resolution involves the reduction, elimination or termination of all forms and types of conflict. Five styles for conflict management as identified by [2] are: competing, compromising, collaborating, avoiding and accommodating, while according to [3], properly managed disputes increase organisational learning by increasing the number of questions asked and encourages people to challenge the status quo.

Over the years three distinct views have evolved about conflict in commercial contracts. The traditional view (dominant from the late nineteenth century until the mid-1940s) assumes that conflict is bad, primarily has negative impacts, can lead to the decline in performance as the level of conflict increases and that Conflict must therefore always be avoided. In this perspective, conflict is closely associated with such terms as violence, destruction and irrationality and the likes. The response to conflict in the traditional view then becomes to reduce, suppress or eliminate it. The behavioural or contemporary view, also known as the human relations view, emerged in the late 90s and held sway through the 1970s. This perspective urges that conflict is natural and inevitable in all organisations and that it may have either a positive or a negative effect on performance, depending on how the conflict is handled.

Project performance may increase with conflict but only up to a certain level, and then decline if conflict is allowed to increase further or is left unsolved. This approach advocates acceptance of conflict and rationalises its existence. Because of the potential benefits from conflict, project managers should focus on managing it effectively rather than suppressing or eliminating it. 
The newest perspective, the interactionist view assumes that conflict is necessary to increase performance while behavioural approach accepts conflict. The interactionist view encourages conflict based on the belief that a harmonious, peaceful tranquil, too-cooperative project organization is likely to become static, stagnant, and unable to respond to change and innovation. This approach encourages managers in commercial contracts to maintain an appropriate level of conflict enough to keep projects self-critical, visible, creative, and innovative [4].

In Nigeria, the construction industry has been paramount in development of the country but little or no funds are allocated to conflict management and dispute resolution, the efforts made are from the stake holders themselves, issues patterning to conflict management and dispute resolution in commercial contracts are time consuming and quite expensive. The problem at the heart of this research is to investigate the subject matter of Conflict and Dispute Resolution in Project-based organisations and commercial contracts and appraise the organisational compliance to available systems, styles, models, views or strategies deployed within project-based organisations in the construction industry.

\section{LITERATURE}

The word conflict comes from the Latin word conflictus, which means collision or clash. [5] considers Conflict as incompatible behavior between parties whose interests differ. The identification of threat, or actual occurrence of conflict, is necessary for the initiation of conflict prevention or management measures, and hence important to address the concept of conflict before seeking how to prevent and manage such occurrences. Conflict is an act of opposing interests involving scarce resources, goal divergence and frustration [6]. Conflict is a struggle or contest between people with opposing needs, ideas, beliefs, values, or goals [7]. Conflict is an existing state of disagreement or hostility between two or more people [8].

\section{A. Conflict Management}

Conflict management involves limiting the negative aspects of conflict while increasing the positive aspects of conflict. Its aim is to enhance learning and group outcomes, including effectiveness or performance in organisational settings (Rahim, 2002), and properly managed conflict can improve group outcomes [9].
Table 1: Sources of Conflict and suggested solutions. (Source: [10])

\begin{tabular}{|c|c|c|}
\hline $\begin{array}{l}\text { Sources of } \\
\text { Conflict }\end{array}$ & Definitions & $\begin{array}{l}\text { Suggested } \\
\text { Solutions }\end{array}$ \\
\hline $\begin{array}{l}\text { Conflict over } \\
\text { project } \\
\text { priorities }\end{array}$ & $\begin{array}{l}\text { Views of project } \\
\text { participants differ over } \\
\text { sequence of activities } \\
\text { and tasks. Includes } \\
\text { goals incompatibility } \\
\text { and differences in } \\
\text { long-term versus } \\
\text { short-term } \\
\text { perspectives. }\end{array}$ & $\begin{array}{l}\text { Develop a master } \\
\text { plan compatible } \\
\text { with long-term } \\
\text { strategies. }\end{array}$ \\
\hline $\begin{array}{l}\text { Conflict over } \\
\text { technical } \\
\text { opinions and } \\
\text { performance } \\
\text { trade-offs }\end{array}$ & $\begin{array}{l}\text { Disagreements over } \\
\text { technical issues, } \\
\text { performance } \\
\text { specifications, and } \\
\text { technical trade-offs. }\end{array}$ & $\begin{array}{l}\text { Use peer review } \\
\text { and steering } \\
\text { committees to } \\
\text { review } \\
\text { specifications } \\
\text { and design. }\end{array}$ \\
\hline $\begin{array}{l}\text { Conflict over } \\
\text { human } \\
\text { resources }\end{array}$ & $\begin{array}{l}\text { Conflicts concerning } \\
\text { staffing and allocation } \\
\text { of project personnel } \\
\text { and where to get them } \\
\text { and how. }\end{array}$ & $\begin{array}{l}\text { Develop a work } \\
\text { breakdown } \\
\text { structure and a } \\
\text { corresponding } \\
\text { responsibility } \\
\text { matrix. }\end{array}$ \\
\hline $\begin{array}{l}\text { Conflict over } \\
\text { cost and budget }\end{array}$ & $\begin{array}{l}\text { Conflict over cost } \\
\text { estimates from } \\
\text { support areas } \\
\text { regarding work } \\
\text { breakdown structures } \\
\text { and estimating } \\
\text { techniques. }\end{array}$ & $\begin{array}{l}\text { Develop overall } \\
\text { budgets } \\
\text { supported by } \\
\text { detailed budget } \\
\text { and cost } \\
\text { estimates of } \\
\text { subproject tasks } \\
\text { and activities }\end{array}$ \\
\hline $\begin{array}{l}\text { Conflict over } \\
\text { schedules }\end{array}$ & $\begin{array}{l}\text { Disagreements about } \\
\text { the timing, } \\
\text { sequencing, and } \\
\text { scheduling of project } \\
\text { related tasks and } \\
\text { information system to } \\
\text { prepare and monitor } \\
\text { project schedules. }\end{array}$ & $\begin{array}{l}\text { Develop an } \\
\text { overall schedule } \\
\text { that integrates } \\
\text { schedules for } \\
\text { subprojects with } \\
\text { staffing and } \\
\text { other life } \\
\text { constraints. }\end{array}$ \\
\hline $\begin{array}{l}\text { Personality } \\
\text { conflict }\end{array}$ & $\begin{array}{l}\text { Disagreements on } \\
\text { interpersonal issues. }\end{array}$ & $\begin{array}{l}\text { Emphasize team } \\
\text { building and } \\
\text { create an } \\
\text { environment that } \\
\text { emphasizes } \\
\text { respect, } \\
\text { diversity, and } \\
\text { equality. }\end{array}$ \\
\hline
\end{tabular}

\section{B. Conflict Prevention}

The prevention of violent conflicts became important early after the end of the Cold War. Cases like Rwanda, Bosnia-Herzegovina and Somalia pointed to the necessity of finding means to avert conflicts from escalating into war, 
human disasters and regional instability. The purpose of international action to deal with such situation was to curtail the spread of violence and find a solution at an early stage and according to [11], Conflict Prevention was born out of these ambitions.

Being more nuanced and asking questions about which actions, and by whom, are more likely to get an effective response [12], as experiences have shown that it is not enough merely to take any preventive action and get some response.

The discussion quickly focused on efforts to resolve conflicts before violence had escalated too far as experience suggests that taking early action is of great importance. Conflicts should be averted early on if disputes are to be avoided and [13] agrees that acting in a full-blown war is the costliest and most dangerous way of intervening and also the one least likely to succeed. If the potential for conflict prevention is to be improved, the sources of its successes and failures must be better understood.

\section{Dispute Resolution}

Early movements within organisational research examined conflict with a view to reducing it, or even eliminating completely, from the context of organisational processes and work. The main objective was to solve conflict in the sense of reducing its amount, instead of attempting to manage it, which does not necessarily imply such a reduction [14]. Such an approach to conflict originated from the use of negative value-laden definitions of conflict, which led to the assumption that the latter has only destructive effects and should therefore be avoided altogether. Theories in Organisations have currently reached a consensus that moderate amounts of conflict is necessary for attaining optimum levels of organizational effectiveness, and that the relation between the latter and conflict approximates an inverted-U function [15]. [16] further posits that while a low level of conflict leads to stagnation, uncontrolled conflict may cause chaos.

Some optimum level of conflict - and associated personal stress and tension - is necessary for progress and productivity, according to studies by [17]. This helps to serve as a means of social change and of an increase in the adaptability of organisations, since the latter learns to adapt to changing internal pressures. It eliminates sources of dissatisfaction and readjusts the balance of power [18]. However, conflict may also have dysfunctional effects. For instance, it may threaten the emotional well-being of individuals by the rupture of their social relationships with other individuals within the group. It can also be the source of misperceptions, withholding information and of suspicious, hostile attitudes which increase sensitivity to differences and threats, while minimising awareness of similarities.

Taking into account that conflict may have positive effects, while keeping in mind that organisational groups are complex networks of interdependencies, giving rise to constant and inevitable sources of conflicts, there is no longer any question of how to eliminate conflict from the workplace. Rather, there is a rising interest in understanding the conditions that lead to the effective management of conflict situations. For instance, a review of conflicts having detrimental consequences for both organisational members and their work context reveals that these instances refer to situations in which conflict has escalated to a certain point and thus failed to be managed. It is only by following the process of conflict, and by understanding how it evolves through time, that we will understand the mechanisms inherent in the conflict situation, as well as detecting mechanisms leading to either escalation or resolution of this situation. This will be of vital importance for both organisational researchers and practitioners, in the sense that it will provide "a link for moving from abstract conceptualisation to organisational application [19].

\section{METHODS}

\section{A. Study Area}

The results used in this study were obtained from Six (6) representative states of the six (6) geopolitical zones of the Federal Republic of Nigeria, as well as the Federal Capital Territory.

\section{B. Data Collection}

The source of data for the study was both primary and secondary sources of data, with the secondary data obtained from peer-reviewed journal articles on the subject matter of Conflict Management and Dispute Resolution. The primary sources were obtained from a Questionnaire Survey and some interviews.

Table 2 Distribution of Questionnaires to Target Groups

\begin{tabular}{|l|l|l|l|}
\hline Category & Distributed & Returned & \% Returned \\
\hline Contractors & 30 & 25 & 83 \\
\hline Consultants & 20 & 18 & 90 \\
\hline Clients & 20 & 10 & 50 \\
\hline Total & 70 & 53 & 76 \\
\hline
\end{tabular}

\section{Method of Analysis}

The descriptive and inferential statistical method, including pie charts, frequency tables and graphs will be used in order to translate the data collected into useful information and to summarize them for proper use in decision making. The online Survey Monkey Tool will be used in formulating and distributing the questionnaire to respondents e-mail and will also be used to analyse the data received by respondents.

\section{RESULTS AND DISCUSSION}

This section presents results and analysis of the questionnaire survey which seeks to appraise the arbitration compliance levels of the Nigerian Construction Industry. 


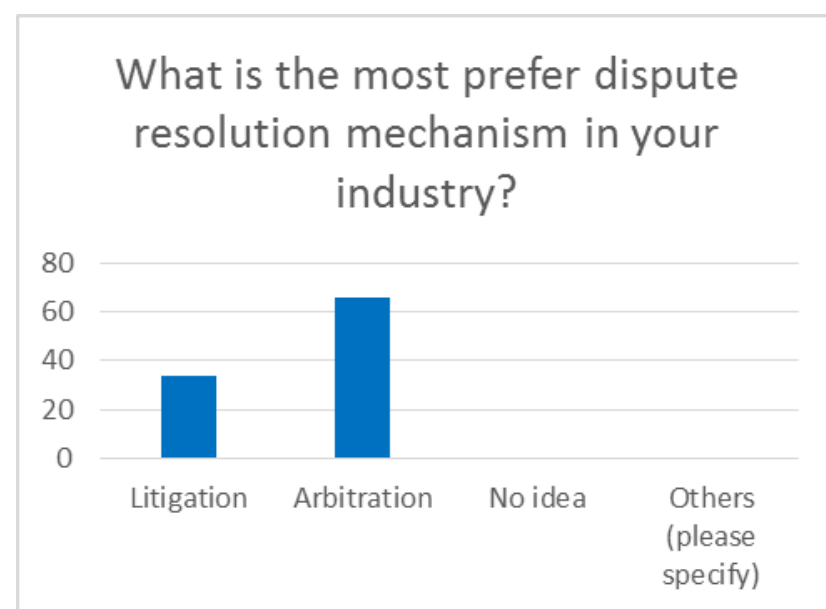

Fig. 1: Distribution of respondents by most preferred dispute resolution mechanism

Table 3 : Percentage of respondents by most preferred dispute resolution mechanism

\begin{tabular}{|l|l|l|}
\hline Answer choices & Percentage & Frequency \\
\hline Litigation & $33.96 \%$ & 18 \\
\hline Arbitration & $66.04 \%$ & 35 \\
\hline No idea & $0.00 \%$ & 0 \\
\hline Other & $0.00 \%$ & 0 \\
\hline Total & & 53 \\
\hline
\end{tabular}

DISCUSSION: Table 3 and Fig 1 show the distribution of respondents by the most preferred dispute resolution mechanism in which 18 respondents (33.96\%) chose Litigation, while 35 respondents $(66.04 \&)$ chose Arbitration. This is as a result of the fact that Arbitration is better and more flexible than Litigation, hence helps to save more time and money.

\section{How suited is arbitration in your industry?}

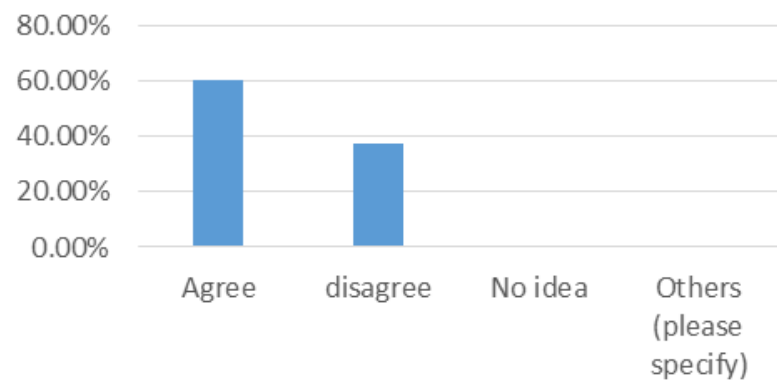

Fig. 2: Is Arbitration suited to your industry?

Table 4 Is Arbitration suited to your industry?

\begin{tabular}{|l|l|l|}
\hline Answer choices & Percentage & Frequency \\
\hline Agree (Yes) & $60.38 \%$ & 32 \\
\hline Disagree (No) & $37.74 \%$ & 20 \\
\hline Undecided & $1.89 \%$ & 1 \\
\hline Others & $0.00 \%$ & 0 \\
\hline Total & & 53 \\
\hline
\end{tabular}

DISCUSSION: Table 4 and Fig. 2 show the distribution of respondents by how suited arbitration is in a particular industry in which 32 respondents $(60.38 \%)$ agreed while 20 respondents $(37.74 \%)$ disagreed and $1(1.89 \%)$ respondent had no idea. Arbitration is widely suited in many industries because it involves less formality than litigation and retains the privacy and confidentiality of the parties.

\section{Is it effective to use outside counsel and experts during dispute resolution?}

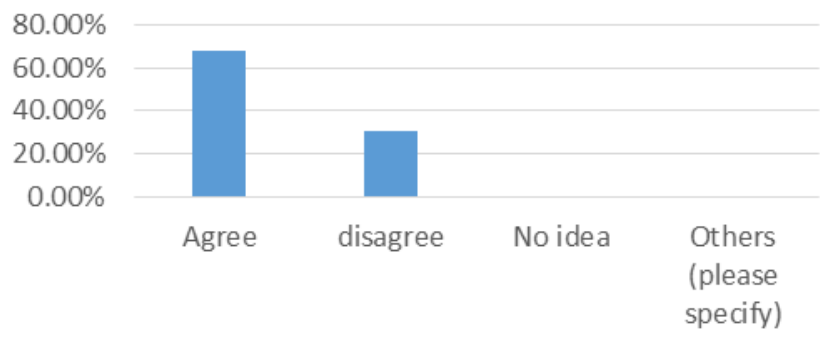

Fig. 3: Is it effective to use outside counsel and experts during dispute resolution?

Table 5 Is it effective to use outside counsel and experts during dispute resolution?

\begin{tabular}{|l|l|l|}
\hline $\begin{array}{l}\text { Answer } \\
\text { choices }\end{array}$ & Percentage & Frequency \\
\hline Agree (Yes) & $67.92 \%$ & 36 \\
\hline Disagree (No) & $30.19 \%$ & 16 \\
\hline No idea & $0.00 \%$ & 1 \\
\hline Total & & 53 \\
\hline
\end{tabular}

DISCUSSION: The result above shows that $36(67.92 \%)$ respondents agreed on the implementation of outside counsel to being effective during dispute resolution while 16 $(30.19 \%)$ disagreed to it saying that in the arbitration process, the parties select the arbitrators that ultimately decide the case in contrast, in many courts, no individual judge is assigned to a case and, therefore, multiple judges may be involved in adjudicating pre-trial disputes.

\section{How Important Is It for Outside Counsel to Be Someone of the Same Profession/Discipline}

$80.00 \%$

$60.00 \%$

$40.00 \%$

$20.00 \%$

$0.00 \%$

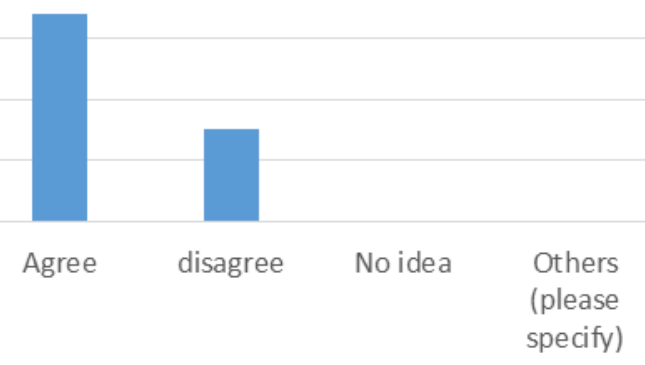

Fig. 4: How Important Is It for Outside Counsel to Be Someone of the Same Profession/Discipline? 
Table 6 How Important Is It for Outside Counsel to Be Someone of the Same Profession/Discipline?

\begin{tabular}{|l|l|l|}
\hline Answer Choices & Percentage & Frequency \\
\hline Agree & $67.92 \%$ & 36 \\
\hline Disagree & $30.19 \%$ & 16 \\
\hline No Idea & $1.89 \%$ & 1 \\
\hline Total & & 53 \\
\hline
\end{tabular}

DISCUSSION: The result above shows that $36(67.92 \%)$ of respondents agreed to the importance of outside counsel being someone of the same profession/discipline, while 16 $(30.19 \%)$ disagreed saying that arbitrators are selected from a pool of professionals, typically with experience in construction industry and therefore, may provide greater level of expertise than a judge or a professional arbitrator with specialty in another profession. Such persons should have a greater capability to comprehend project issues and documents and to scrutinize liability and damages claims common to the construction industry than most trial judges.

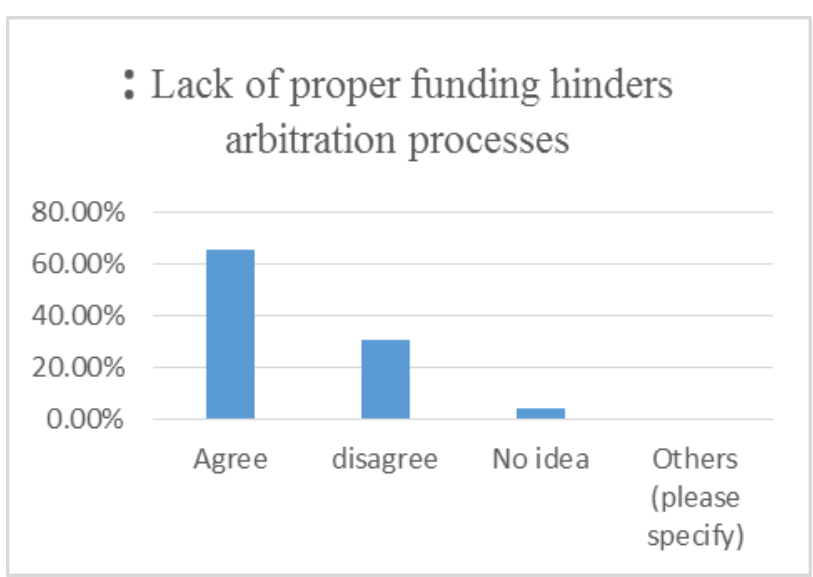

Fig. 5: Lack of proper funding hinders arbitration processes

Table 7 Lack of proper funding hinders arbitration processes

\begin{tabular}{|l|l|l|}
\hline Answer Choices & Percentage & Frequency \\
\hline Agree & $65.38 \%$ & 34 \\
\hline Disagree & $30.77 \%$ & 16 \\
\hline No idea & $3.85 \%$ & 2 \\
\hline Total & & 53 \\
\hline
\end{tabular}

DISCUSSION: Fig. 5 above extracted responses on how lack of proper funding delayed the arbitration processes in which $34(65.38 \%)$ respondents agreed to the statement and $16(30.77 \%)$ disagreed. Arbitration often is less costly than litigation, primarily due to the compressed scheduled for completion of discovery and trial.in court litigation, significant expenses are devoted to pre-trial discovery processes, such as written interrogations and depositions of witnesses. However, the discovery process that is prevalent in litigation increasingly has become a regular part of arbitration as well, thus increasing cost.

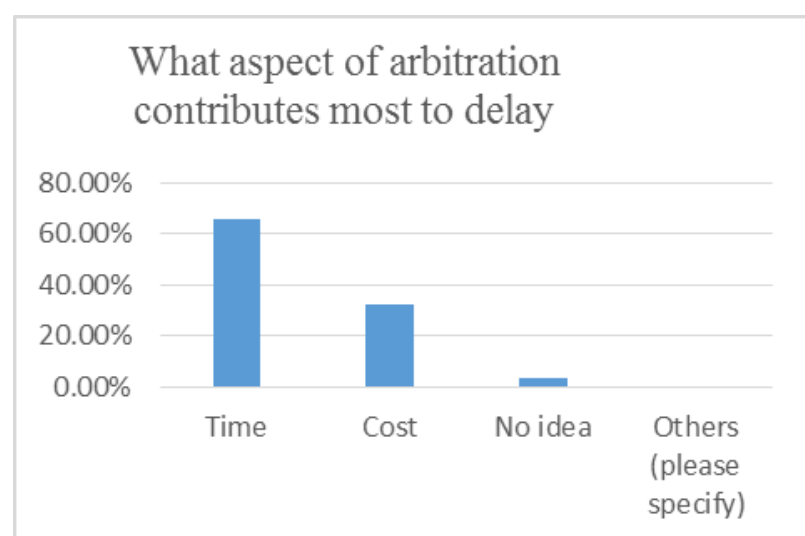

Fig. 6: What aspect of arbitration contributes most to delay?

Table 8 What aspect of arbitration contributes most to delay?

\begin{tabular}{|l|l|l|}
\hline Answer choices & Percentage & Frequency \\
\hline Time & $66.03 \%$ & 35 \\
\hline Cost & $32.08 \%$ & 17 \\
\hline No idea & $1.89 \%$ & 1 \\
\hline Total & & 53 \\
\hline
\end{tabular}

DISCUSSION: The result above shows that 35 (66.04\%) of respondents chose time and $17(32.08 \%)$ chose cost, while $1(1.89 \%)$ had no idea. In this aspect of arbitration, it has been agreed that time has been the major factor that contributes most to delay. In special cases the time taken to settle the dispute may be longer than expected and in other cases an outside counsel must be consulted before proper settlements can be reached.

\section{CONCLUSION AND RECOMMENDATIONS}

The management of construction projects is influenced by clients, contractors, consultants and stakeholders, hence it is important that the study reveals how Cost plays a less important role than Time, in terms of causing delays to construction projects in Nigeria, as against some theories which believe Cost to be the major cause of delays in projects. This corroborates the decision of the respondents to preferring Arbitration to Litigation in the Nigerian Construction Industry, due to its less expensive and time-wasting nature. It is therefore recommend that Arbitration be the most accepted Dispute Resolution method employed by parties to a Construction Project, due to its flexible, cost-effective, private and binding nature. This study also recommends that Project-based organisations invest more in effect long term organisational/project strategies to ensuring that conflicts never escalate to disputes, by negotiating and implementing only International Forms of Contracts which include Arbitration Clauses. 


\section{ACKNOWLEDGMENT}

The authors acknowledge the efforts of Francis Asuquo, Collins Oguoba, Kelvin Obi and Patrick Gabriel, all students of the Civil Engineering department of the Cross River University of technology, for their contributions to this study as Undergraduate students.

\section{REFERENCES}

[1] M. A. Rahim, (2002). "Toward a Theory of managing organisational conflict". The International Journal of conflict Management, Vol. 13. NO.3. pp. 206-235.

[2] K. W. Thomas, and R. H. Kilmann, (2007). Technical brief for Mode Instrument, (Revised Edition), Mountain View, CA: CPP Inc.

[3] F, Luthans, et al., (1995). "Going beyond total quality: The characteristics, techniques and measures of learning organisations". International Journal of organisational Analysis.3:24-44.

[4] P. Jeffrey, (1998): The project management institute project management handbook (ed) ISBN 0-7879-4013-5.

[5] L.D. Brown, (1983). Managing conflict at organisational interfaces. Reading, Mass: Addison-Wesley.

[6] N. L. Swanstronm.and,M. S. Weissmann "Conflict Prevention and Conflict Management and Beyond: A conceptual Exploration” Uppsala University Press.ISBN:91-85473-02-2.

[7] E. Pia and T. Diez (2007)." Conflicts and human Rights: A Theoretical Framework. Human Rights in conflicts: The Role of civil Society. University of Birmingham Press.

[8] M. Nicholson (1992).Rationality and the Analysis of International conflict (Cambridge University Press).

[9] S. Alpert, et al., (2000). "Conflict management efficiency and performance in organisation terms". Personal Psychology 53:pp.625-642

[10] V. K. Verma (1998), Conflict management. The project management Institute Project Management Handbook, Ed Jeffrey pinto.

[11] P. Wallensteen (2002) Understanding Conflict Resolution. War, Peace and the Global System, London: Sage.

M, S. Lund (2002) "Preventing violent Intrastate conflicts: Learning lessons from experience" In van Tongeren, paul et al., (eds) (2002) Searching for peace in Europe and Eurasia. An overview of conflicts prevention and peace building activities, London: Lynee rienner Publishers, Inc.

K. A. Annan (1996) "The peace keeping prescription" in cahill, kevin M (ed) (1996) preventive diplomacy. Stopping war before they start, New York: Basic book and the center for international health and co-operation.

V. Wall and L. Nolan (1986) Perceptions of inequity, satisfaction
A. Rahim and T. Bonoma (1979) Managing Organizational Conflicts: A model for diagnosis and intervention. Psychological Reports, 44, pp.1323-1344.

D. R. Hampton et al., (1973).Organizational Behaviour and the practice of management. Glenview: Scott, Foreman. $2^{\text {nd }}$ edition.

[17] L. R. Pondy (1967).Organisational Conflicts: Concepts and models Administrative science Quarterly, 12 (2), pp.296-320.

[18] M. Deutsch (1973). The Resolution of conflict: Constructive and Destructive processes. New Haven, Conn,: Yale university Press.

[19] T. A. Kochan and A. Verma (1983). Negotiations In organisations: Blending industrial relations and organizational behaviour approaches. In M.H. Baxerman \& R.J. Levicki (eds) Negotiating in organisations (pp.13-32) London: sage. and conflict in task-Oriented Groups. Human Relations, 39, (11), pp.1033-1052. 